Jurnal Agribisnis Vol: 18 No: 2 Desember 2016 ISSN-P: 1412-4807 ISSN O: 2503-4375

ANALISIS TINGKAT EFESIENSI PENGUNAAN FAKTOR PRODUKSI

USAHATANI PADI VARIETAS UNGGUL NASIONAL, UNGGUL LOKAL DAN HIBRIDA PADA SAWAH TADAH HUJAN DI KECAMATAN BANGKINANGKABUPATEN KAMPAR

\author{
1) Jamaluddin \\ 1) Staff Pengajar Fakultas Pertanian Universitas Islam Kuantan Singingi \\ Email : fit_jamal@yahoo.com
}

Tujuan dari penelitian ini adalah untuk penggunaan faktor produksi, biaya produk, produksi pendapatan dan efisiensi usahatani padi sawah tadah hujan varietas unggul nasional, unggul lokal dan hibrida di Kecamatan Bangkinang Seberang. Penelitian ini menggunakan metode survey. Teknik pengambilan sampel petani padi sawah tadah hujan dilakukan dengan memakai metode Malti Stake Sampling dan jumlah petani sebanyak 90 orang. Analisis efisiensi teknis adalah penggunaan faktor produksi yang optimal untuk menghasilkan produksi yang maksimal. Efisiensi teknis diperoleh dari hasil perkalian antara elastisitas produksi dengan produksi dan dibagi dengan rata - rata input, efisiensi penggunaan input secara teknis ini tercapai pada saat Nilai produk marjinal (NPM) sama dengan produksi rata-rata (PR). Koefisien regresi dari ketiga varietas yang sekaligus menjadi koefisien elastisitas dari faktor produksi, dengan demikian dapat disimpulkan bahwa Luas Lahan, Benih, Pupuk Urea, Pupuk SP36, Pupuk NPK, Pupuk Organik, Pestisida dan Tenaga kerja yang dialokasikan oleh petani belum efisien secara teknis karena, nilai koefisien regresinya tidak sama dengan nol. Sedangkan secara ekonomis, diperoleh nilai rasio antara nilai produk marjinal $\mathrm{X}_{\mathrm{i}}$ dengan harga $X_{i}$ untuk Luas lahan, Benih, Pupuk, Pestisida dan Tenaga kerja maka pengalokasiannya belum efisien secara ekonomis..

Kata kunci : padi, varietas unggul lokal, varietas unggul nasional,hibrida, sawah tadah hujan, usaha tani

\title{
PENDAHULUAN
}

Pemerintah senantiasa memberi perhatian besar bagi upaya peningkatan produksi padi. Berbagai program telah dicanangkan dan di implementasikan guna memacu produksi padi. Sistem penyediaan sarana dan prasarana pertanian juga terus di sempurnakan agar petani lebih produktif berusahatani. Untuk memenuhi kebutuhan beras orientasi kebijakan perberasan harus mengarah kepada upaya peningkatan kemandirian pangan.

Pemerintah kabupaten Kampar melalui petugas pertanian lapangan (PPL) mengupayakan setiap petani untuk menanam varietas padi unggul yang diusahakan oleh petani, dan menyediakan benih padi tersebut di setiap daerah yang belum mengusahakan varietas padi unggul. Namun petani banyak mengunakan berbagai varietas yang diusahakan petani di kecamatan Bangkinang 
Seberang, berdasarkan survei dilakukan dilapangan varietas yang banyak digunakan untuk Varietas Ungul Lokal adalah 1). Anak Daro, 2). Pandan Wangi dan 3). Sunting Mas. Varietas Ungul Nasional adalah 1). IR 42 dan 2). Cisokan. Varietas Hibrida Adalah 1). Bernas Prima dan 2). Bernas Super.

Perbedaan varietas unggul nasional, unggul lokal dan hibrida, padi yang ditanam petani, kemungkinan akan terdapat pula perbedaan pengunaan input, biaya produksi, dan produksi yang dihasilkan, dimana pada akhirnya akan dapat pula berpengaruh terhadap pendapatan petani. Namun sejauh ini peningkatan produksi padi sawah tadah hujan dari masing-masing varietas padi tersebut belum diketahui, begitu pula pendapatan yang diperoleh oleh petani. Masih kurangnya pengetahuan petani tentang efisiensi penggunaan faktor produksi seperti pengolahan lahan, pengunaan benih, pemupukan, pengunaan pestisida dan tenaga kerja sehinga upaya peningkatan produksi dan pendapatan usahatani padi sawah tadah hujan dapat menjadi terhambat. Berkaitan dengan itulah saya tertarik ingin melakukan penelitian ini.

Tujuan dari penelitian ini adalah untuk mengetahui efensiensi ekonomis usahatani padi sawah tadah hujan varietas unggul nasional, unggul lokal dan hibrida di Kecamatan Bangkinang Seberang.

\section{METODELOGI PENELITIAN}

Metode yang digunakan dalam penelitian ini adalah survei. Penelitian ini dilakukan di kecamatan Bangkinang Seberang kabupaten Kampar. Penetapan daerah penelitian ini dilakukan secara sengaja dengan pertimbangan bahwa di kecamatan tersebut terdapat petani padi sawah tadah hujan yang mengusahakan berbagai varietas seperti varietas unggul nasional, unggul lokal dan hibrida.

Populasi dalam penelitian ini adalah petani padi sawah tadah hujan yang menggunakan varietas unggul nasionsl, unggul lokal dan hibrida di Kecamatan Bangkinang Sebrang. Teknik pengambilan sampel petani padi sawah tadah hujan dilakukan dengan memakai metode Malti Stake Sampling.

Efisiensi ekonomis merupakan hasil kali antara seluruh efisiensi teknis dengan efisiensi harga atau alokatif dari seluruh faktor input. Efisiensi ekonomi dapat diartikan juga sebagai kombinasi input yang dapat memaksimumkan tujuan seorang individu atau tujuan sosial masyarakat.

119 Analisis Tingkat Efesiensi Pengunaan Faktor Produksi Usahatani Padi Varietas Unggul Nasional, Unggul Lokal Dan Hibrida Pada Sawah Tadah Hujan Di Kecamatan Bangkinangkabupaten Kampar 
Tingkat efisiensi ekonomis diperoleh bila turunan pertama dari faktor pendapatan bersih sama dengan nol.

$$
\begin{gathered}
\pi=Y . P y-X . P x-T F C \\
\frac{d \pi}{d X}=P y \frac{d Y}{d X}-P x=0 \\
=\mathrm{Py} . \mathrm{MPPx}-\mathrm{Px} \\
\mathrm{NPMx}-\mathrm{Px}=0 \\
N P M=P x \text { atau } \frac{N P M x}{P x}=1
\end{gathered}
$$

Efisiensi ekonomis faktor-faktor produksi dapat dijelaskan sebagai berikut:

Jika NPMx > Px, penggunaan faktor produksi belum efisien secara ekonomis

Jika NPMx < Px, penggunaan faktor produksi tidak efisien secara ekonomis

Jika NPMx = Px, penggunaan faktor produksi efisien secara ekonomis.

Menurut Soekartawi (2005), efisiensi penggunaan faktor produksi dapat Sdibedakan menjadi 3 yaitu: 1). Efisiensi teknis, 2). Efisiensi alokatif dan 3). Efesiensi ekonomis. Namun yang digunakan dalam penelitian ini adalah ekonomis.

\section{HASIL DAN PEMBAHASAN}

\section{Efisiensi Ekonomis}

Efisiensi ekonomis diartikan sebagai upaya penggunaan faktor produksi yang sekecil-kecilnya untuk memperoleh keuntungan sebesar-besarnya. Suatu usahatani telah efisien secara ekonomis bila nilai produk marjinal sama dengan harga faktor produksi, atau rasio antara nilai produk marjinal dengan harga imput sama dengan satu (Soekartawi, 2003).

\section{Varietas IR 42}

120 Analisis Tingkat Efesiensi Pengunaan Faktor Produksi Usahatani Padi Varietas Unggul Nasional, Unggul Lokal Dan Hibrida Pada Sawah Tadah Hujan Di Kecamatan Bangkinangkabupaten Kampar 
Dapat diketahui bahwa efesiensi ekonomis penggunaan faktor produksi pada usahatani padi sawah tadah hujan dari penggunaan varietas IR 42 dapat dilihat pada Tabel 1 dibawah ini.

Tabel 1. Efesiensi Ekonomis Penggunaan Faktor Produksi Luas Lahan, Benih dan Pestisida Pada Varietas IR 42.

\begin{tabular}{|c|c|c|c|c|c|c|}
\hline FP & $X_{i}($ Unit $)$ & $\begin{array}{c}\text { PM } \\
(\mathrm{b})\end{array}$ & Px (Rp/Unit) & NPM (Rp) & X.Px & Rasio \\
\hline L. Lahan & 0,40 & 0,515 & $2.957 .227,7$ & $4.923 .790,73$ & $1.182 .891,08$ & 4,16 \\
\hline Benih & 17,20 & $-0,085$ & 103.200 & $-754.094,08$ & $1.775 .040,00$ & $-0,42$ \\
\hline P.Urea & 54,50 & $-0,035$ & 130.100 & $-310.509,33$ & $7.090 .450,00$ & $-0,04$ \\
\hline P. SP 36 & 55,30 & $-0,041$ & 145.250 & $-363.739,50$ & $8.032 .325,00$ & $-0,05$ \\
\hline P. NPK & 27,33 & 0,012 & 80.310 & $106,460,34$ & $2.194 .881,59$ & 0,05 \\
\hline P.Organik & 39,50 & $-0,004$ & 39.500 & $-35.486,78$ & $1.560 .250,00$ & $-0,023$ \\
\hline Pestisida & 1,05 & 0,041 & 89.668 & $363.739,50$ & $94.151,40$ & 3,86 \\
\hline T.Kerja & 110,89 & 0,356 & 5.168 .860 & $3.158 .323,42$ & $584.064 .885,40$ & 0,005 \\
\hline
\end{tabular}

Keterangan:

Rata-rata produksi $(\mathrm{y})=2.534,77$

Harga produksi $(\mathrm{py})=3.500$

$\mathrm{X}_{\mathrm{i}} \quad$ : Rata-rata Penggunaan Faktor Produksi

PM : Produk Marjinal/Elastisitas Produksi

Px : Harga Faktor Produksi

NPM : Nilai Produk Marjinal (b.Y.Py)

X.Px : Faktor Produksi dikali Harga Faktor Produksi

Rasio : NPM dibagi X.Px

Rasio antara nilai produk marjinal lahan $\left(\mathrm{NPM} \mathrm{X}_{1}\right)$ dengan harga XPX adalah sebesar 4,16. Rasio ini memiliki makna bahwa setiap Rp. 1 biaya yang dikeluarkan atas kepemilikan lahan bersifat elastis terhadap pendapatan, sehingga penambahan luas lahan akan berpengaruh terhadap peningkatan pendapatan, ini berarti secara ekonomis penggunaan luas lahan oleh petani belum efisien karena nilai rasio yang diperoleh lebih besar dari satu $(4,16>1)$. Untuk mencapai efisiensi ekonomis, petani harus menambah luas lahan yang digunakan untuk berusahatani padi sawah tadah hujan, sehinga pendapatan yang maksimal akan diperoleh petani.

Rasio untuk penggunaan benih $\left(\mathrm{X}_{2}\right)$ memiliki rasio sebesar -0,42 dimana untuk mencapai efisiensi maka jumlah penggunaan benih harus dikurangi karena penambahan benih akan menyebabkan berkurangnya pendapatan, yaitu setiap $\mathrm{Rp}$. 
1 biaya yang dikeluarkan untuk benih akan mengurangi pendapatan sebesar Rp, 0,42. Karena penggunaan benih sudah berlebihan.

Rasio untuk penggunaan pupuk Urea $\left(\mathrm{X}_{31}\right)$ memiliki rasio sebesar -0,04 dimana untuk mencapai efisiensi maka jumlah penggunaan pupuk Urea harus dikurangi karena penambahan pupuk Urea akan menyebabkan berkurangnya pendapatan, yaitu setiap Rp. 1 biaya yang dikeluarkan untuk pupuk Urea akan mengurangi pendapatan sebesar Rp, 0,04. Karena penggunaan pupuk Urea sudah berlebihan.

Rasio untuk penggunaan pupuk SP $36\left(\mathrm{X}_{32}\right)$ memiliki rasio sebesar -0,05 dimana untuk mencapai efisiensi maka jumlah penggunaan pupuk SP 36 harus dikurangi karena penambahan pupuk SP 36 akan menyebabkan berkurangnya pendapatan, yaitu setiap Rp. 1 biaya yang dikeluarkan untuk pupuk SP 36 akan mengurangi pendapatan sebesar Rp, 0,05. Karena penggunaan pupuk SP 36 sudah berlebih.

Rasio yang diperoleh untuk penggunaan pupuk NPK $\left(\mathrm{X}_{33}\right)$, adalah sebesar 0,05 secara ekonomis penggunaan pupuk NPK harus dikurangi karena nilai rasionya lebih kecil dari satu $(0,05<1)$, artinya setiap Rp. 1 biaya yang dikeluarkan untuk pupuk NPK akan diperoleh pendapatan kotor yang lebih kecil bila dibandingkan dengan biaya yang dikeluarkan untuk penggunaan pupuk tersebut.

Rasio untuk penggunaan pupuk Organik $\left(\mathrm{X}_{34}\right)$ memiliki rasio sebesar -0,023 dimana untuk mencapai efisiensi maka jumlah penggunaan pupuk Organik ini justru jumlahnya harus dikurangi karena penambahan pupuk Organik akan menyebabkan berkurangnya pendapatan, yaitu setiap Rp. 1 biaya yang dikeluarkan untuk pupuk Organik akan mengurangi pendapatan sebesar Rp, 0,023. Karena penggunaan pupuk organik sudah berlebih.

Rasio untuk Pestisida $\left(\mathrm{X}_{4}\right)$ memiliki rasio sebesar 3,86 Rasio ini memiliki makna bahwa setiap Rp. 1 biaya yang dikeluarkan atas penggunaan pestisida bersifat elastis terhadap pendapatan, sehingga penambahan pestisida tidak berpengaruh terhadap peningkatan pendapatan, ini berarti secara ekonomis penggunaan Pestisida oleh petani belum efisien karena nilai rasio yang diperoleh lebih besar dari satu $(3,86>1)$. Untuk mencapai efisiensi ekonomis, petani harus 
menambah pengunaan pestisida yang digunakan untuk berusahatani padi sawah, sehinga pendapatan yang maksimal akan diperoleh petani.

Rasio yang diperoleh untuk tenaga kerja $\left(\mathrm{X}_{5}\right)$, adalah sebesar 0,005 secara ekonomis penggunaan tenaga kerja harus dikurangi karena nilai rasionya lebih kecil dari satu $(0,005<1)$, artinya setiap Rp. 1 biaya yang dikeluarkan untuk tenaga kerja akan diperoleh pendapatan kotor yang lebih kecil bila dibandingkan dengan biaya yang dikeluarkan untuk tenaga kerja tersebut.

Dari uraian sebelumnya maka secara umum dapat diartikan bahwa penggunaan faktor produksi oleh petani sampel belum efisien secara ekonomis, dengan demikian secara ekonomis, maka hipotesis $3 ; \mathrm{H}_{\mathrm{o}}$ yang menyatakan bahwa pengalokasian faktor produksi oleh petani belum mencapai tingkat efesiensi secara ekonomis dapat diterima dan hipotesis $3 ; \mathrm{H}_{\mathrm{a}}$ ditolak.

\section{Varietas Anak Daro}

Dapat diketahui bahwa efesiensi ekonomis penggunaan faktor produksi pada usahatani padi sawah tadah hujan dari penggunaan varietas Anak Daro dapat dilihat pada Tabel 2 dibawah ini.

Tabel 2. Efesiensi Ekonomis Penggunaan Faktor Produksi Luas Lahan, Benih dan Pestisida Pada Varietas Anak Daro.

\begin{tabular}{|c|c|c|c|c|c|c|}
\hline FP & $X_{i}$ (Unit) & $\begin{array}{c}\text { PM } \\
(\mathrm{b})\end{array}$ & Px (Rp/Unit) & NPM (Rp) & X.Px & Rasio \\
\hline L. Lahan & 0,55 & 0,234 & $3.913 .038,90$ & $2.746 .950,57$ & $2,152,171.40$ & 1,28 \\
\hline Benih & 23,07 & 0,007 & 138.400 & $8.217,37$ & $3,192,888.00$ & 0,003 \\
\hline P. Urea & 83,17 & 0,000 & 199.433 & 0.000 & $16,586,870.06$ & 0,000 \\
\hline P.SP36 & 64,53 & 0,037 & 165.400 & $434.346,89$ & $10,673,262.00$ & 0,04 \\
\hline P.NPK & 44,6 & $-0,012$ & 124.783 & $-140.869,26$ & $5,565,304.41$ & $-0,025$ \\
\hline P. Organik & 37 & 0,015 & 36.956 .52 & $176.086,58$ & $1,367,391.24$ & 0,13 \\
\hline Pestisida & 1,51 & 0,128 & 133.567 & $1.502 .605,44$ & $201,686.17$ & 7,45 \\
\hline T.Kerja & 147,75 & 0,151 & 8.864 .716 & $1.772 .604,86$ & $1,309,761,789.00$ & 0,0014 \\
\hline
\end{tabular}

Keterangan:

Rata-rata produksi $(\mathrm{y})=3.354,03$

Harga produksi $(\mathrm{py})=3.500$

$\mathrm{X}_{\mathrm{i}} \quad$ : Rata-rata Penggunaan Faktor Produksi

PM : Produk Marjinal/Elastisitas Produksi

Px : Harga Faktor Produksi

NPM : Nilai Produk Marjinal (b.Y.Py)

X.Px : Faktor Produksi dikali Harga Faktor Produksi

Rasio : NPM dibagi X.Px 
Rasio antara nilai produk marjinal lahan (NPM $\mathrm{X}_{1}$ ) dengan harga X.PX adalah sebesar 1,28. Rasio ini memiliki makna bahwa setiap Rp. 1 biaya yang dikeluarkan atas kepemilikan lahan bersifat elastis terhadap pendapatan, sehingga penambahan luas lahan akan berpengaruh terhadap peningkatan pendapatan, ini berarti secara ekonomis penggunaan luas lahan oleh petani belum efisien karena nilai rasio yang diperoleh lebih besar dari satu $(1,28>1)$. Untuk mencapai efisiensi ekonomis, petani harus menambah luas lahan yang digunakan untuk berusahatani padi sawah tadah hujan, sehinga pendapatan yang maksimal akan diperoleh petani.

Rasio untuk penggunaan benih $\left(\mathrm{X}_{2}\right)$ memiliki rasio sebesar 0,003 dimana secara ekonomis penggunaan benih harus dikuranggi karenanilai rasionya lebih kecil dari satu $(0,003<1)$ artinya setiap Rp. 1 ,- biaya yang dikeluarkan untuk benih akan diperoleh pendapatan kotor yang lebih kecil bila dibandingkan dengan biaya yang dikeluarkan untuk benih tersebut.

Rasio untuk penggunaan pupuk Urea $\left(\mathrm{X}_{31}\right)$ memiliki rasio sebesar 0,00 dimana secara ekonomis penggunaan pupuk Urea harus dikuranggi karenanilai rasionya lebih kecil dari satu $(0,00<1)$ artinya setiap Rp. 1,- biaya yang dikeluarkan untuk pupuk Urea akan diperoleh pendapatan kotor yang lebih kecil bila dibandingkan dengan biaya yang dikeluarkan untuk pupuk tersebut.

Rasio untuk penggunaan pupuk SP $36\left(\mathrm{X}_{32}\right)$ memiliki rasio sebesar 0,04 dimana secara ekonomis penggunaan pupuk SP 36 harus dikuranggi karenanilai rasionya lebih kecil dari satu $(0,04<1)$ artinya setiap Rp. 1,- biaya yang dikeluarkan untuk pupuk SP 36 akan diperoleh pendapatan kotor yang lebih kecil bila dibandingkan dengan biaya yang dikeluarkan untuk pupuk tersebut.

Rasio untuk penggunaan pupuk NPK $\left(\mathrm{X}_{33}\right)$ memiliki rasio sebesar $-0,025$ dimana untuk mencapai efisiensi maka jumlah penggunaan pupuk NPK ini justru jumlahnya harus dikuranggi karena penambahan pupuk NPK akan menyebabkan berkurangnya pendapatan, yaitu setiap Rp. 1 biaya yang dikeluarkan untuk pupuk NPK akan mengurangi pendapatan sebesar Rp, 0,025. Karena penggunaan pupuk NPK sudah berlebih.

Rasio untuk penggunaan pupuk Organik $\left(\mathrm{X}_{34}\right)$ memiliki rasio sebesar 0,13 dimana secara ekonomis penggunaan pupuk Organik harus dikuranggi 
karenanilai rasionya lebih kecil dari satu $(0,13<1)$ artinya setiap Rp. 1 ,- biaya yang dikeluarkan untuk pupuk Organik akan diperoleh pendapatan kotor yang lebih kecil bila dibandingkan dengan biaya yang dikeluarkan untuk pupuk tersebut.

Rasio untuk Pestisida $\left(\mathrm{X}_{4}\right)$ memiliki rasio sebesar 7,45 Rasio ini memiliki makna bahwa setiap Rp. 1 biaya yang dikeluarkan atas penggunaan pestisida bersifat elastisitas terhadap pendapatan, sehingga penambahan pestisida tidak berpengaruh terhadap peningkatan pendapatan, ini berarti secara ekonomis penggunaan Pestisida oleh petani belum efisien karena nilai rasio yang diperoleh lebih besar dari satu $(7,45>1)$. Untuk mencapai efisiensi ekonomis, petani harus menambah penggunaan pestisida yang digunakan untuk berusahatani padi sawah, sehinga pendapatan yang maksimal akan diperoleh petani.

Rasio yang diperoleh untuk penggunaan tenaga kerja $\left(\mathrm{X}_{5}\right)$, adalah sebesar 0,0014, secara ekonomis penggunaan tenaga kerja harus dikurangi karena nilai rasionya lebih kecil dari satu $(0,0014<1)$, artinya setiap Rp. 1 biaya yang dikeluarkan untuk tenaga kerja akan diperoleh pendapatan kotor yang lebih kecil bila dibandingkan dengan biaya yang dikeluarkan untuk tenaga kerja tersebut.

Dari uraian sebelumnya maka secara umum dapat diartikan bahwa penggunaan faktor produksi oleh petani sampel belum efisien secara ekonomis, dengan demikian secara ekonomis, maka hipotesis $3 ; \mathrm{H}_{\mathrm{o}}$ yang menyatakan bahwa pengalokasian faktor produksi oleh petani belum mencapai tingkat efesiensi secara ekonomis dapat diterima dan hipotesis $3 ; \mathrm{H}_{\mathrm{a}}$ ditolak.

\section{Varietas Super Bernas}

Dapat diketahui bahwa efesiensi ekonomis penggunaan faktor produksi pada usahatani padi sawah tadah hujan dari penggunaan varietas Super Bernas dapat dilihat pada Tabel 3 dibawah ini. 
Tabel 3. Efesiensi Ekonomis Penggunaan Faktor Produksi Luas Lahan, Benih dan Pestisida Pada Varietas Super Bernas.

\begin{tabular}{|c|c|c|c|c|c|c|}
\hline FP & $X_{i}$ (Unit) & $\begin{array}{c}\text { PM } \\
\text { (b) }\end{array}$ & Px (Rp/Unit) & NPM (Rp) & X.Px & Rasio \\
\hline L. Lahan & 0,50 & 0,010 & 4.054 .517 & $121.635,50$ & $2.027 .258,50$ & 0,06 \\
\hline Benih & 23,43 & $-0,102$ & 140.600 & $-1.240 .682,10$ & $3.294 .258,00$ & $-0,38$ \\
\hline P. Urea & 65 & 0,032 & 152.167 & $389.233,60$ & $9.890 .833,55$ & 0,04 \\
\hline P.SP 36 & 42 & 0,032 & 102.002 & $389.233,60$ & $4.284 .091,14$ & 0,09 \\
\hline P. NPK & 43 & $-0,029$ & 119.767 & $-352.742,95$ & $5.149 .966,81$ & $-0,07$ \\
\hline P. Organik & 52 & 0,057 & 51.667 & $693.322,35$ & $2.686 .684,00$ & 0,26 \\
\hline Pestisida & 1,49 & $-0,086$ & 131.233 & $-1.046 .065,30$ & $195.537,17$ & $-5,35$ \\
\hline T.Kerja & 152,65 & 0,783 & 9.183 .940 & $9.524 .059,65$ & $1.401 .928,44$ & 6,794 \\
\hline
\end{tabular}

Keterangan:

Rata-rata produksi $(\mathrm{y})=3,475.30$

Harga produksi $(\mathrm{py})=3.500$

$\mathrm{X}_{\mathrm{i}} \quad$ : Rata-rata Penggunaan Faktor Produksi

PM : Produk Marjinal/Elastisitas Produksi

Px : Harga Faktor Produksi

NPM : Nilai Produk Marjinal (b.Y.Py)

X.Px : Faktor Produksi dikali Harga Faktor Produksi

Rasio : NPM dibagi X.Px

Rasio antara nilai produk marjinal lahan $\left(\mathrm{NPM} \mathrm{X}_{1}\right)$ dengan harga XPX adalah sebesar 0,06. Dimana secara ekonomis penggunaan lahan harus dikurangi karena nilai rasionya lebih kecil dari satu $(0,06<1)$ artinya setiap $\mathrm{Rp}$. 1,- biaya yang dikeluarkan untuk lahan akan diperoleh pendapatan kotor yang lebih kecil bila dbandingkan dengan biaya yang dikeluarkan untuk lahan karena dengan menambah luas lahan dengan perawatan kurang baik akan menghasilkan produksi lebih sedikit.

Rasio untuk penggunaan benih $\left(\mathrm{X}_{2}\right)$ adalah sebesar $-0,38$ dimana untuk mencapai efisiensi maka jumlah penggunaan benih ini justru jumlahnya harus dikurangi karena penambahan benih akan menyebabkan berkurangnya pendapatan, yaitu setiap Rp. 1 biaya yang dikeluarkan untuk benih akan mengurangi pendapatan sebesar Rp, 0,38. Karena penggunaan benih oleh petani sudah berlebih.

Rasio untuk penggunaan pupuk Urea $\left(\mathrm{X}_{31}\right)$ adalah sebesar 0,04 dimana secara ekonomis penggunaan pupuk Urea harus dikurangi karena nilai rasionya 
lebih kecil dari satu $(0,04<1)$ artinya setiap Rp. 1,- biaya yang dikeluarkan untuk penggunaan pupuk Urea akan diperoleh pendapatan kotor yang lebih kecil bila dibandingkan dengan biaya yang dikeluarkan untuk pupuk tersebut.

Rasio untuk penggunaan pupuk SP $36\left(\mathrm{X}_{32}\right)$ adalah sebesar 0,09 dimana secara ekonomis penggunaan pupuk SP 36 harus dikuranggi karenanilai rasionya lebih kecil dari satu $(0,09<1)$ artinya setiap Rp. 1,- biaya yang dikeluarkan untuk pupuk SP 36 akan diperoleh pendapatan kotor yang lebih kecil bila dibandingkan dengan biaya yang dikeluarkan untuk pupuk tersebut.

Rasio untuk penggunaan pupuk NPK $\left(\mathrm{X}_{33}\right)$ adalah sebesar -0,07 dimana untuk mencapai efisiensi maka jumlah penggunaan pupuk NPK ini justru jumlahnya harus dikurangi karena penambahan pupuk NPK akan menyebabkan berkurangnya pendapatan, yaitu setiap Rp. 1 biaya yang dikeluarkan untuk pupuk NPK akan mengurangi pendapatan sebesar Rp, 0,07. Karena penggunaan pupuk NPK sudah berlebih.

Rasio untuk penggunaan pupuk Organik $\left(\mathrm{X}_{34}\right)$, adalah sebesar 0,26 secara ekonomis penggunaan pupuk Organik harus dikurangi karena nilai rasionya lebih kecil dari satu $(0,26<1)$, artinya setiap Rp. 1 biaya yang dikeluarkan untuk pupuk Organik akan diperoleh pendapatan kotor yang lebih kecil bila dibandingkan dengan biaya yang dikeluarkan untuk penggunaan pupuk tersebut.

Rasio untuk Pestisida $\left(\mathrm{X}_{4}\right)$ adalah sebesar -5,35 dimana untuk mencapai efisien maka jumlah pengunaan Pestisida ini justru harus dikurangi karena penambahan pestisida akan menyebabkan berkurangnya pendapatan, yaitu setiap Rp. 1,- biaya yang dikeluarkan untuk pestisida akan mengurangi pendapatan sebesar Rp.5,35. Karena pengunaan berlebihan.

Rasio untuk Tenaga kerja $\left(\mathrm{X}_{5}\right)$ memiliki rasio sebesar 6,794 Rasio ini memiliki makna bahwa setiap Rp. 1 biaya yang dikeluarkan atas penggunaan tenaga kerja bersifat elastisitas terhadap pendapatan, sehingga penambahan tenaga kerja tidak berpengaruh terhadap peningkatan pendapatan, ini berarti secara ekonomis penggunaan tenaga kerja oleh petani belum efisien karena nilai rasio yang diperoleh lebih besar dari satu $(6,794>1)$. Untuk mencapai efisiensi ekonomis, petani harus menambah penggunaan tenaga kerja yang digunakan untuk berusahatani padi sawah, sehinga pendapatan yang maksimal akan diperoleh petani. 
Dari uraian sebelumnya maka secara umum dapat diartikan bahwa penggunaan faktor produksi oleh petani sampel belum efisien secara ekonomis, dengan demikian secara ekonomis, maka hipotesis 3, ; $\mathrm{H}_{\mathrm{o}}$ yang menyatakan bahwa pengalokasian faktor produksi oleh petani belum mencapai tingkat efesiensi secara ekonomis dapat diterima dan hipotesis $3, ; \mathrm{H}_{\mathrm{a}}$ ditolak.

\section{KESIMPULAN DAN SARAN}

\section{Kesimpulan}

- Koefisien regresi dari ketiga varietas yang sekaligus menjadi koefisien elastisitas dari faktor produksi, dengan demikian dapat disimpulkan bahwa Luas Lahan, Benih, Pupuk Urea, Pupuk SP36, Pupuk NPK, Pupuk Organik, Pestisida dan Tenaga kerja yang dialokasikan oleh petani belum efisien secara teknis karena, nilai koefisien regresinya tidak sama dengan nol. Sedangkan secara ekonomis, diperoleh nilai rasio antara nilai produk marjinal $X_{i}$ dengan harga $X_{i}$ untuk Luas lahan, Benih, Pupuk, Pestisida dan Tenaga kerja maka pengalokasiannya belum efisien secara ekonomis.

\section{Saran}

1. Untuk memperoleh produksi dan pendapatan yang maksimal, maka pengalokasikan input harus optimal, dengan demikian di harapkan kepada petani untuk menambahkan Luas lahan, pupuk dan menambah pestisida. Kemampuan petani perlu ditingkatkan melalui penyuluhan tentang penggunaan sarana produksi terhadap usahatani padi sawah dan pengolahan usahatani yang lebih baik dan mengurangi biaya produksi.

2. Dari penguna sarana produksi usahatani padi sawah berdasarkan penelitian yang telah dilakukan yang perlu ditingkatkan adalah penambahan luas lahan, pengunaan pestisida serta pengalokasian tenaga kerja.

3. Petani lebih mengoptimalkan penggunaan benih, pupuk, pestisida sesuai dengan luas lahan dan menanam varietas padi sawah yang sesuai dengan kondisi keadaan tekstur lahan sawah tadah hujan.

4. Kepada instansi yang terkait pada peningkatan produksi dan pendapatan petani maka disarankan untuk dapat memfasilitasi petani dalam pengadaan 
sarana produksi, minsalnya dengan memberikan bantuan dan subsidi kepada petani padi sawah.

\section{DAFTAR PUSTAKA}

Abbas, 1997. Revolusi Hijau dengan Swasembada Beras dan Jagung, Jakarta.

Adiratma E., 2004. Stop Tanaman Padi. Penebar Swadaya, Jakarta.

Adiningsih. S .1999. Ekonomi Mikro, Edisi Pertama, BPFE, Yogyakarta

Asrol. 2001. Analisis Ekonometrik Fungsi Produksi Padi di Kabupaten Kampar. Jurnal Dinamika Pertanian , 12 (3); 82 - 87.

Assauri S., 1989. Pengantar Ekonomi Makro. FE-UI, Jakarta.

Aziz, N. 2003 . Pengantar Mikro Ekonomi, Aplikasi dan manajemen, Bayume dia Publishing, Malang

Banoewidjojo, M. 1983. Pembangunan Pertanian, Usaha Nasional, Surabaya.

Dewi, S dan Idris. 2005. Efesiensi Produksi Sistem Usahatani Padi Pada Lahan Sawah

IrigasiTeknis.http://ejournal.unud.ac.id/abstrak/\%287\%29\%20soca-

dewi\%20sahara\%20dan\%20indris-efisiensi\%20produksi\%281\%29.pdf (22

Februari 2012)

Hernanto, F., 1992. Ilmu Usahatani. Penerbit Swadaya, Jakarta.

Husni AM., Sudi M dan Mewa A. 2003. Faktor-faktor Yang Mempengaruhi Produksi, Konsumsi dan Harga Beras Serta Inflansi Bahan Makanan. Onlen pada http://pse.litbang.deptan.go.id/ind/pdffiles/JAE22-2b.pdf. di aksespada (22 Februari 2012)

Jafar A. Gani, Netal, 2000. Balai Pengkajian Teknologi Pertanian. Lembar Informasi Pertanian. Depertemen Pertanian, Mataram.

Jamil, Octavianus Agust, Yulfahri, Ika Purwani, Ida Nuristina, 2009. Teknologi Budidaya Padi Mendukung Operasi Pangan Riau Makmur, DIPA BPTP RIAU TA 2009.

Kadariah, 1981. Pembangunan Pertanian. PT. Raja Grafindo Perkasa. Jakarta.

Kasryno, 1981. Lan Tenure and Lan Relation in West Java A Case Study in For Village,Agroekonomi Study, Jakarta.

Kamal, M., 1991. Analisa Usahatani Digalakan. Sinar Tani, Jakarta.

129 Analisis Tingkat Efesiensi Pengunaan Faktor Produksi Usahatani Padi Varietas Unggul Nasional, Unggul Lokal Dan Hibrida Pada Sawah Tadah Hujan Di Kecamatan Bangkinangkabupaten Kampar 
Mubyarto, 1983. Politik Pertanian dan Pembangunan Pertanian. Sinar Harapan, Jakarta.

---------, 1989. Pengantar Ilmu Pertanian.LP3 ES, Jakarta.

--------, 1994. Pengantar Ekonomi Pertanian. Lembaga Penelitian, Pendidikan dan Penerangan Ekonomi dan Sosial (LP3 ES). Jakarta.

Noor, 1996. Padi Lahan Marginal. Penebar Swadaya, Jakarta.

Rachman Arjulis, Eliarti, Umar, 2006. Budidaya Padi Gogo Padi Sawah, dan Padi Pasang Surut. DIPA BPTP RIAU TA 2006.

Saputra A.L, (2012) http://epetani.deptan.go.id/budidaya/budidaya-padi-sawahspesifikasi-lokasi-tadah-hujan-di-kecamatan-anyar-4507 Diakses tanggal 11 April 2012.

Soekartawi .2002. Teori Ekonomi Produksi, Dengan Pokok Bahasan Analisis Fun gsi Cobb-Douglas, PT. Raja Grafindo Persada, Jakarta .

Soekartawi, 1987. Prinsip Dasar Ekonomi Pertanian Teori dan Aplikasinya. Rajawali Pres. Jakarta.

Suparyono A S., 1993. Padi, Penebar Swadaya, Jakarta.

Sugiono, 2001. Metode penelitian bisnis. C.V. Alfabetta Bandung

---------, 1991. Agribisnis Teori dan Aplikasinya. Rajawali Pres, Jakarta.

--------, 1993. . Agribisnis Teori dan Aplikasinya. PT. Raja Grafindo Perkasa. Jakarta.

1995. Prinsip Dasar Ekonomi Pertanian Teori dan Aplikasi, PT. Raja GronfindoPersada, Jakarta.

--------, 2002. Teori Ekonomi Produksi. Raja Gronfindo Persada, Jakarta.

Sinurya S., 1985. Dasar - dasar Akuntansi. Fakultas Ekonomi, Universitas Sumatra Utara, Medan.

Sigit, S. 1994. Analisis Break Even Rancangan Linier Secara Ringkas dan Praktis. BPFE Yogyakarta.

Sukirno. S. 1985. Pengantar Teori Makro Ekonomi. Rajawali Press. Jakarta.

Susanto, Harry. 2044. Analisis Pendapatan dan Efesiensi Penggunaan Faktor Produksi Usahatani Padi Gogo Secara Tumpangsari Dengan Jagung di Kecamatan Kadipaten Tasikmalaya Propinsi Jawa Barat. Skripsi. Jurusan Ilmu-ilmu Sosial Ekonomi Pertanian, Fakultas Pertanian, Institut Pertanian Bogor, Bogor

130 Analisis Tingkat Efesiensi Pengunaan Faktor Produksi Usahatani Padi Varietas Unggul Nasional, Unggul Lokal Dan Hibrida Pada Sawah Tadah Hujan Di Kecamatan Bangkinangkabupaten Kampar 
Susetyo. B, 2010. Statistika Untuk Analisis Data Penelitian, Pt Refika Aditama, Jl. Mengger Girang No. 98, Bandung.

Yasin F.A.Z, Saipul Bahri, Ahmad Rifai, Djaimi, Azharuddin, 2002. Analisis Struktur Biaya dan Ekonomi Usahatani Padi Sawah Atas Kebijakan Haega Pupuk di Kabupaten Kampar, Jurnal Dinamika Pertanian, 17 (9); 128 139. 